\title{
Non-Lysosomal Glucosylceramidase
}

National Cancer Institute

\section{Source}

National Cancer Institute. Non-Lysosomal Glucosylceramidase. NCI Thesaurus. Code C104426.

Non-lysosomal glucosylceramidase $(927, \sim 105 \mathrm{kDa}$ ) is encoded by the human GBA2 gene. This protein plays a role in the generation and prevention of glycolipid accumulation. 